\title{
JUSTICE DAY
}

\section{Nicolae Popa, PhD}

Former President of the Constitutional Court and the High Court of Cassation and Justice

Each year, since 1993, Justice Day is celebrated at the beginning of July. And each year, the festivities are attended by representatives of the other powers, but this year no leaders of such powers honoured us with their presence. Each time, speeches are made to emphasise progress in the delivery of justice, while also addressing future prospects. This year was no different. Speeches talked about the nobleness of a judge's work, the advantages of implementing the new codes, the praises of European controllers and their encouragements on the line of "persuasive punishments". Emphasis was placed on the need to respect the independence of the judiciary, under conditions of attempts to infringe this principle coming from the legislature, the executive, the media, etc.

The opening address uttered by the President of the High Council for the Magistrature even manifested a vision that was close to the perspective of philosophical - legal analysis, by showing, in essence, that the judicial establishment is built on the independence of the judge, as no superior in the hierarchy of this establishment can give orders to the judge.

No approaches were made toward more "delicate" issues in the conduct of judicial procedures, which have caused reactions in society and which have not been appropriately tackled by authorised structures.

With respect to the reactions of some professional judges' associations (AMR, for example), we believe that avoiding debate on fundamental matters of the operation of justice in the representative body of magistrates (CSM) cannot be a desirable solution. It is increasingly more difficult to explain why terms are not joined in relation, namely independence with responsibility and with impartiality. Thus, even non-experts already know that the independence and irrevocability of judges are of constitutional origin, that the principle of independence, repeated on any given occasion, should not be judged abstractly. It cannot become, in an actual way, an effective principle of organising judicial power unless it exists as a reality of this organisation. The independence of the judiciary cannot be transformed into a privilege sheltering abuse or incompetence. The European Court of Human Rights has long noted this. For example, in the case of Pullar v. United Kingdom, in 1996, the Court retained that the judges must not manifest personal preferences and prejudice and that, at the same time, a court of law must offer sufficient guarantees to remove any legitimate doubt in this respect. We chose this example from ECHR 
Popa, N. (2015)

Justice Day

jurisprudence, from nearly 20 years ago, to underline once again the need to eliminate from the conduct of judges (not to mention prosecutors) any behavioural reflexes that are likely to involve "personal preferences and prejudice" in their judging work or attitudes entailing "legitimate doubts" regarding the failure to observe trial guarantees (the Rarinca case is the most recent that comes to mind). Of course, this was not an appropriate topic for "Justice Day", all the more since, in their vast majority, judges serve their high mission in a professional and dignified manner. It is for this very reason that the excesses of some colleagues (some of whom, unfortunately, have positions as high as the High Council for the Magistrature) should awaken the conscience of the devoted and fair.

In the last 25 years justice has made significant progress. The body of judges was gradually renewed, so today we may speak of judges trained in a proportion of $90 \%$ after 1990, in faculties which fully reorganised their legal training process. The integration of judges in the new judicial structures was generally made without major obstacles. In the content of interhuman relations there have been evident changes. These, in their turn, have constituted true challenges for those who carry out the act of justice, and the components of judicial power were faced with casuistry of enormous complexity. A lot was said during this period of the separation of power and the position of judicial power. Alexander Hamilton, one of the ideological masterminds of the American Constitution, was convinced that the judicial power was the weakest of the 3 corridors of power. Over time, things have changed; judges have reinforced their position, which was in part due to the not at all insignificant fact that they were involved in the resolution of cases with an increased "technical load". Thus, a true "judicialisation of politics" occurred; we might speak of a borderline "government of judges" (or, more recently, in these parts, of a "republic of prosecutors", which is something different). Lord Ralf Dahrenolorf even believed that the strongest the judicial power is in a country, the slower the pace of reform. Such remarks come right under the conditions of influence of new factors configuring the law imposed by the process of globalisation of the plurality of sources of law, of legal "grafts", and to the backdrop of increasing risks involved by the presence of these new factors. The judge, often denigrated, lives in the middle of these mutations and is faced with controlling those who diversify the sources of law (especially in the framework of control of constitutionality), with overseeing the observance of the limits of legal competences by various authorities (especially in administrative courts), but most of all with ensuring the right measure for guaranteeing human dignity. Idealistically speaking, a judge must love the blue sky and freedom, life and justice, beauty and truth. A judge is also the bearer of the juridical spirit towards that guides the life of each person and which is, ultimately, the factor determining humans to find the meaning given by daily existence. This is the basis of his 
immense responsibility ${ }^{1}$, since a judge is not only the bearer of the juridical spirit but also the one who, through the justness of his resolutions, contributes to reinforcing this spirit in the collective awareness. He is the one who can, for example, turn an evil (a punishment), inasmuch as the person who incurs it is aware of the fact that it is justly established, into an expression of good.

This is what Steinhardt demonstrates (in his Journal of Happiness) when he shows that, through the agency of what is just, evil transforms into good.

The requirement of responsibility for judges is perfectly legitimated by the ever stronger need, asserted in today's European societies, to increase the quality of justice, to simplify and streamline judicial procedures. In the accomplishment of this endeavour one cannot talk, of course, of a judge as regarded in isolation, alone and unsupported by society or the partners of a judicial process ${ }^{2}$.

The independence, irrevocability and allegiance of a judge to law only are prerequisites of the manifestation of the principle of uniqueness, impartiality and equality of justice, and they appear as true constitutional axioms. The realisation of these axioms lies with the judge (first and foremost, since he is the one that closes the circle) but also with all those who participate, in some quality or other, in the act of justice, since allegiance to law is not an obligation that rests solely with the judge. Unfortunately, sometimes (or oftentimes), the well-known methods of diversion are employed. Confusions are created intentionally. The activity of the judge is equated to that of the prosecutor and it is not infrequently that the prosecutor is believed to be accomplishing the act of justice. Other times, criminal justice is treated as an absolute, forgetting that, of all cases referred to a judge, criminal cases have a share of $18-20 \%$, the rest being extra-criminal cases. The experience of the last years has demonstrated that the political discourse (especially at the top) was marked by insistent (and programmed) actions to oppose participants in the judicial process, to divide them into opposing sides (we are obviously talking of criminal trials). Those who support the prosecution have usually been placed on the good side. Judges would pertain to the other side. In principle, the purpose of the prosecution can only be that of contributing, according to legal competences, to the realisation of the act of justice by identifying the person suspected of having committed a crime, by interpreting and presenting legally obtained evidence, as free from doubt as possible, which would be unmistakable for the characterisation of the suspect's criminal behaviour.

In order for the purpose of a criminal trial to be accomplished by the judge it is imperiously necessary for the latter to ensure the equality of weapons between the prosecution and the defence. The defender is entirely worthy of appreciation for the professional and honest effort made in order to achieve the purpose of justice. The truth can never be captive, confiscated by one party, and the judicial process would forever be contested if the judge were to tip the balance for one side only, in 
absence of the right to contestation, of the duel borne with the sword of arguments. I remember the considerations on talent made by the late Professor Doctor Mihai Constantinescu, former judge at the Constitutional Court, in an exciting work: "Prosecutors are not men of order, nor are lawyers those of disorder; the former are not guardian angels of society, nor are the latter those who would prevent them from achieving their mission. That is why there is no reason to exalt the prosecution as the only one that does its duty"3. Society, beneficiary of the public service called justice, supports the process of its responsibilisation and the quality operation of its mechanisms, evincing a genuine interest for the closeness of such mechanisms to people, who need the correct operation of justice (as they need the correct operation of education, health, government, etc.).

In the countries that monitor us (post European Union accession) there is also a vivid concern for tracking how the mechanisms of justice operate. Here I bring only a few examples collected by myself from international contacts in the period when I was the President of the Constitutional Court or President of the Supreme Court of Justice.

At the Bucharest 2004 International Legal Conference, attended by presidents of Constitutional Courts and Supreme Courts from over 30 countries in Europe, the USA, and Asia, Ivan Verougstraete, President of the Belgian Cassation, referring to the operation of the judiciary in Western Europe, mentioned that in Western Europe most citizens seemed to be dissatisfied with the judiciary, although, in general, judges were not corrupt and were most of the time technically qualified. However, in their vast majority, people were hostile to the legal system. Even if this can be seen as an irrational behaviour induced by tabloid journals or TV journalists of doubtful quality, this dissatisfaction is a fact no government can afford to ignore.

In France, a sociological research commented by Marie - Luce Cavroix, Hubert Dale and Jean Paul Jean revealed the fact that $66 \%$ of the French citizens questioned believed that the operation of justice was defective, $73 \%$ accused the slowness of justice, and, in a different register, the French recognised, in a proportion of $65 \%$, that they were afraid of justice, and $54 \%$ considered justice to be partial (Matthieu Boissary and Thomas Clay).

Is justice in crisis? Appearances would indicate as much. A careful analysis, this time dedicated to Romanian justice, is likely to seriously nuance such a conclusion. The reform of the Romanian judiciary has never been a topic of profound concern for the Romanian political society. Sometimes aberrant projects were approached (Macovei ministry), with revanchist tones and without a minimal understanding of the fact that substantial changes in the system are only possible if the mentalities and reflexes of the legislator and judge are prepared for this. Other times, only a segment of reform was tackled, the remuneration of judges (Stoica ministry), very 
Popa, N. (2015)

Justice Day

important but incomplete inasmuch as no consideration was given to the not at all negligible fact that change in the area of norms and institutions is entirely insufficient, "abstract and superficial" (Hegel) if not accompanied by a change in the area of conscience and faith. As a consequence, even if the salaries of members of the judiciary were increased, manifestations of condemnable greed in the behaviour of some judges could not be mitigated / eliminated in all this period.

Having emerged and developed especially in the shadow of French judicial culture, the Romanian judiciary also inherited its flaws - formalism, special inclination to tortuous procedural paths, "appetite" for exceptions and loopholes created through fictions and presumptions, etc. Thus, it was possible for a "culture of slowness" to appear, which fuelled a lack of perspectives in resolving cases. Oftentimes the beauty of contradictory debates between enlightened minds of the bar sacrificed the interest of the parties!

The problems with good operation in Romanian justice are much more complicated than they seem, and their adequate knowledge, as well as debating them with professionalism continues to be a topic of concern for academic media and for representative institutions of the state. Solutions cannot come solely from fragmented appreciations arrived from abroad. Dialogue with European courts is absolutely necessary, provided that it is the result of real consultation with the best informed sources. Otherwise, if the so-called consensus is made with the displayed intention of ascertaining the general deterioration of judicial institutions, the remedies proposed here and there confirm a subversive intention of defending political interests or certain categories of participants in the political debate. We believe it is time for the discourse regarding the state of justice and bringing it to the level of the population's expectations be freed from clichés and petty political prejudice, from superficial, subjective or malevolent appreciations. After all, the Justice of these years is closely linked to the society of these years, and the society of these years too often appears as a "dramatic democracy", in which the massmedia places an excessive emphasis on eliciting feelings of dissatisfaction in the population. Transitioning from jus societatis to jus proprietatis has proved to be a much more complicated endeavour than it seemed at first. The emphasis placed almost exclusively during these years on the right to property transformed the state community of free citizens, proud of their country, into a sort of loose conglomerate of personae in which we start to have difficulty finding our identity. The fact that a society cannot be articulated without a distributive (or corrective) justice criterion was largely lost from sight, and law, beyond its protective/repressive function, must also reclaim a moralising (promotional) function.

I believe that, unfortunately, in these 25 years, outside the constitutional project there has been no major and constant preoccupation for defining the sense of a 
Popa, N. (2015)

Justice Day

clear legislative project, which would also comprise the institutional construction of justice. Most measures were made under the influence of momentary requirements; short-view opportunities were considered, in absence of clear principles and intentions.

I would venture to say that, during this entire period, facing situations of crisis, with attacks from all sides (some of them even entitled!), with ambiguities and approximations, the justice has worked and has represented, on the limit, a pole of stability without which it would be difficult to imagine what would have happened. It has worked with ups and downs, marking moments of true progress, as well as bottlenecks, it has revised its mechanism on the go, it has fought barriers and limits, it has begun, from the inside, a process of professional and moral cleansing, a process which must also be assumed by the other powers. It has been proved that judges are primarily interested in bringing the judicial process to a human scale, to deliver it within an optimal and predictable time, as justice delayed is justice denied.

It is, however, necessary that the state ensure sufficient means; a coherent and stable legislation is needed, in which both citizens and experts would find themselves. Ultimately, the equation is a simple one: an insufficient budget does not allow a sufficient number of judges and auxiliary staff, and this determines an overload of cases, and, consequently, longer terms, the quality of the act of justice being negatively impacted.

Society is, with good reason, extremely demanding of justice. The independence of a judge is, for the citizen, a strong guarantee of an impartial justice. Any act of abdication, by the judge, from the principles of justice means, in the eyes of the people, a true betrayal. Profoundly interested in the good march of justice, people receive the output of its work with entitled hope. Their comments, even when critical, must be taken as an expression of this above-mentioned hope. Solutions entered in res judicata can be submitted to the appraisal of both specialists and citizens.

Personally, I have been (as is well-known) and will remain an outspoken enemy of attacks and criticisms brought to the judicial activities in the case instrumentation phase. Such actions constitute interferences with the judging activity. But to make a taboo of and prohibit de plano any comment (possibly critical) regarding solutions entered in res judicata, claiming that this affects the independence of justice, is an exaggeration.

While participating, as President of the Constitutional Court, at the celebration of the $50^{\text {th }}$ anniversary of the Federal Constitutional Court of Germany (Karlsruhe, 28 September, 2001) I discovered that, far from being declared taboo to critical appraisals, the speakers approached numerous such aspects. The case of Germany is a particular one in the sense that this institution (their Constitutional Court) is, 
Popa, N. (2015)

Justice Day

indeed, a judicial one, since Article 92 in the fundamental law of Germany and Article 1(1) in its law of organisation places it expressly within the system of judicial power. In her keynote address, the President of the Federal Constitutional Court, Professor Doctor Jutta Limbach, recognised that, in a process of ensuring the protection of citizen rights, which had been lasting for over 50 years, disappointments and conflicts were inevitable. Public debates sparked by some controversial decisions constituted an opportunity to assert the idea that public authority is diminished (limited) by fundamental rights and the control exerted on it (by the court). Going further and addressing the President of the Bundestag and the Federal Chancellor, she maintained that: "neither you, Mr. President of the Bundestag, nor your predecessor to this position, agreed with all decisions of the Court. It was only 3 days ago that the Federal Chancellor admonished us, a fact which, within the framework of this ceremony, I would like to declare as a manifestation of the freedom of expression and therefore I shall abstain from commenting it."

Present at the ceremony, the President of Germany, Mr. Johannes Rau, recalled the numerous disputes former Chancellor Conrad Adenamer had had with the Federal Constitutional Court, who also made a resonant declaration: "We weren't expecting it to be quite like this!" The Constitutional Court managed to overcome all this and build a successful career. Evoking and praising this career, President Johannes Rau also remarked the fact that criticisms were levied on some decisions of the Court, since "even the Federal Constitutional Court must endure criticisms". I allowed myself to recall this episode for at least 2 reasons. The first of these concerns the calm, even Olympian we might say, reaction of Ms. President Jutta Limbach. The second one comes from carefully watching the practice of the Federal Constitutional Court of Germany, namely the well-balanced, unobtrusive way in which the court has managed to secure the supremacy of the Fundamental German Law (Grundgestez) and the respect for human dignity.

We believe that the example above reinforces the conclusions that, after the final solutions given by courts enter jurisdictional patrimony, they may (and even must) constitute a topic for debate by both specialists and citizens.

\section{Notes}

${ }^{1}$ See, more broadly, Nicolae Popa - Responsabilitatea Judecatorului, Revista de Drept Public nr. 1-2, 2012.

${ }^{2}$ More broadly, Nicolae Popa - Calitatea Justitiei, Buletinul Casatiei nr. 3/2006.

${ }^{3}$ Mihai Constantinescu - Alegorie la ziua de ieri, Ed. Continent XX1, 1999, p. 179 